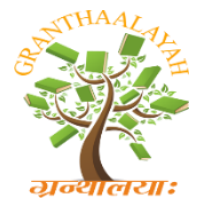

\author{
INTERNATIONAL JOURNAL OF RESEARCH - \\ GRANTHAALAYAH \\ A knowledge Repository
}

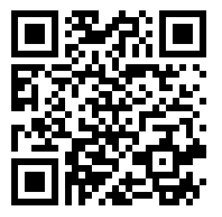

Social

\title{
EMPOWERING ISLAMIC BOARDING SCHOOL IN IMPROVING ITS HUMAN RESOURCES IN BATANG HARI REGENCY JAMBI PROVINCE (THE STUDY AT UMMUL MASAKIN ISLAMIC BOARDING SCHOOLS IN BATANG HARI REGENCY)
}

\author{
Professor Dr. Maisah, M.Pd.I ${ }^{1}$, Professor Dr. H. Martinis Yamin, M.Pd ${ }^{2}$, Dr. Madyan \\ M.Pd.I ${ }^{3}$ \\ ${ }^{1,2,3}$ Dosen UIN Sulthan Thaha Syaifuddin Jambi - Indonesia
}

\begin{abstract}
The existence of Islamic boarding schools in Jambi province, present as a place which give image to Islamic boarding schools that familiarize students to recognize and to study religious knowledge in depth by applying it in the daily lives of the students. Therefore, it will become a habit in the students behavior. Ummul Masaqin Islamic Boarding School is one of the modern Islamic boarding schools which proclaims itself as an open-minded mass organization in the hope that it can be more flexible and more agile to play an active role in solving social problems.

By continuous development of the times, the students are expected to be able to follow these developments. Islamic Boarding Schools see the importance of developing the function of Islamic boarding schools as a center for scientific and religious development, and as a center for the empowerment of students. Therefore, Islamic Boarding Schools made a new breakthrough by carrying out empowerment strategy for their students. This empowerment strategy is an effort of Islamic Boarding Schools to increase the resources of the students.

This research is a field research that uses qualitative research method or approach. The focus of the research is centered on the issue of empowering Islamic boarding school in improving its human resources in Jambi Province, by using data collection techniques: observation, interviews and documentation. The type of data used is primary and secondary data. The data validity technique uses data triangulation.

The research findings are: 1) Ummul Masakin Islamic Boarding School teaching and educating staff recruitment is conducted by planning through estimation of employee requirements and estimation of internal supply of human resources. 2) The empowerment of Islamic boarding schools in improving human resources in the Islamic Boarding School in Batang Hari conductedin the form of (a) Recitation, (b) Al-Qur'an Educational Park, (c) Poskenstren, (d) Kopontren. 3) Islamic Boarding Schools prepares future scholars by empowerment in Ummul Masakin Islamic Boarding School through various activities / coaching, namely: (a) The Development of the Khitabah, (b)The Development of the Kitab Kuning Study.
\end{abstract}

Keywords: Empowerment; Human Resources. 
Cite This Article: Dr. Maisah, Dr. H. Martinis Yamin, and Dr. Madyan. (2019). "EMPOWERING ISLAMIC BOARDING SCHOOL IN IMPROVING ITS HUMAN RESOURCES IN BATANG HARI REGENCY JAMBI PROVINCE (THE STUDY AT UMMUL MASAKIN ISLAMIC BOARDING SCHOOLS IN BATANG HARI REGENCY)." International Journal of Research Granthaalayah, 7(6), 178-189. https://doi.org/10.29121/granthaalayah.v7.i6.2019.786.

\section{Introduction}

\subsection{Background}

Human Resources (HR) has a central position in realizing development performance, which places humans in their functions as development resources. In this context human prices and values are determined by the relevance of their construction to the product process. Human quality is programmed so that it can be in accordance with the demands of development or the demands of society. The existence of the Indonesian nation in the midst of the current global era, will be influenced by the ability of Indonesia's human resources, especially those characterized by the mastery of science and technology and the strengthening of faith and piety towards the Supreme God. This can be sought through education as an alternative.

Education can not be separated from the reality of life in the future, namely the period in which students navigate life. Therefore education must be designed for a better life in the future, as well as the planting of values that are able to provide life in the future, which are sourced from religion must also be given. This includes the quality and excellence of human resource competition, up to the ideal society that is aspired to in accordance with future demands based on Islamic values.

In an Islamic perspective, education has played an important role in efforts to give birth to human beings who are reliable and can answer the challenges of the times. The human resource is a human investment movement is a long-term educational effort to give birth to human resources.

Islamic education has an important role in improving the quality of human resources. In accordance with its characteristics as religious education, it is ideally functioning in the preparation of high-quality human resources, both in mastering science and technology and in terms of character, moral attitude, and appreciation and practice of religious teachings. In short, ideal Islamic education functions to foster and prepare knowledgeable students, technologists, highly skilled and faithful charity.

The main task of Islamic boarding schools in essence is to realize Indonesian people and Islamic communities who have faith and devotion to Allah. The superiority of human resources desired by Islamic boarding schools is the realization of a qualified young generation that is not only on the cognitive, affective and psychomotor aspects, more oriented towards improving the quality of the students towards mastering science and technology based on the noble values of Islamic teachings. The development of human resources is not an easy matter because it requires systematic, systemic, and serious action steps. Because trying to provide a complete construction about humans by developing all the basic human potential. In this case, Islamic boarding schools with all their potential have a role in the ongoing development. 
For this reason, all efforts that refer to the development of human quality as human resources are continuously carried out with an indication of the improvement in the quality of Indonesian people who are able to think strategically and have insight into the future with a balance between IMTAQ and science and technology.

The process of empowering human resources in an educational institution can be done in two ways, namely through education and training. Where for the empowerment of educators and education personnel carried out through training, which can improve the quality and quantity of these personnel in carrying out their duties and can be used to improve the progress of the school. While empowerment in the form of education is intended for students in an educational institution, and does not rule out the possibility accompanied by training owned by the school.

Ummul Masakin Islamic Boarding School is one of the semi-modern salaf Islamic boarding schools which proclaims itself as an open-ended organization in the hope of being able to be more flexible and more agile to play an active role in solving community problems. Education and da'wah are the main programs in Islamic Boarding Schools, without overruling other programs. Islamic Boarding Schools also experience rapid development from time to time. Islamic boarding schools also aim to produce cadres who are mujahid-minded, able to develop their potential so that they can play an active and beneficial role for the community. With the continuous development of the times, the students are expected to be able to follow these developments. Islamic Boarding Schools see the importance of developing the function of Islamic boarding schools as a center for scientific and religious development, and as a center for the empowerment of santri students. Therefore Islamic Boarding Schools made a new breakthrough by carrying out an empowerment strategy for their santri. This empowerment strategy is an effort of Islamic Boarding Schools to increase the resources of the santri.

Therefore, the researchers felt the need to describe the results of the grand tour conducted at the Islamic Boarding School at the Masakin Regency in Batang Hari Regency. In the preliminary study the researchers caught that this boarding school in cottage empowerment showed interesting phenomena to study.

Here in the empowerment of Islamic boarding schools in improving the human resources of Islamic boarding schools held by the head of the cottage. Where the head of the lodge carries out the role as an agent of change. In addition, to improve the human resources of Ummul Masakin Islamic Boarding School has a clear motto after dark, which is the spirit to always strive to improve pesantren human resources, and build excellence by more conducive learning habits by coordinating with teachers and education staff, press meetings in implementing school programs with openness, mutual respect and respect. In this case it is not always the principal who leads the meeting, but is empowered to the representatives and teachers according to their abilities and competencies. Principals and teachers, education staff are always committed to memunyaia high enthusiasm to make changes in empowering all the potential of the cottage.

Another reason for the researchers in determining the location of the research was the Ummul Masaqin Islamic Boarding School empowerment guided by Islamic education. Ummul Masaqin Islamic Boarding School gives the students the freedom to choose the path of education according to their potential. This will encourage the santri at Ummul Masaqin Islamic Boarding School to 
develop their potential so that their independence can be realized, which in turn can help improve their own welfare.

The boarding school also prepared several plans to empower the pesantren's human resources, one of which was by adding to the santri's extracurricular activities with current skills, except that some of the plans that had been made to empower pesantren human resources did not go well, and there were still some obstacles in carry out plans for empowering Islamic boarding schools to improve Islamic boarding school human resources. Departing from the background of the problem, researchers have an interest in finding out more about "Empowering Islamic Boarding Schools in Increasing Human Resources in Islamic Boarding Schools in Jambi Province".

\subsection{Problem Formulation}

1) How is the planning for recruitment of human resources (teaching staff, and educational staff / staff) in Islamic boarding schools in Jambi Province?

2) What is the empowerment of Islamic boarding schools in improving pesantren human resources in Jambi Province?

3) What are the results of the empowerment of Islamic boarding schools in improving human resources at Islamic Boarding Schools in Jambi Province?

\subsection{Focus of Research}

1) Recruitment planning for human resources (teaching staff, and educational staff / staff) in Islamic boarding schools in Jambi Province.

2) Empowering Islamic boarding schools in improving Islamic boarding school human resources in Jambi Province.

3) The results of the empowerment of Islamic boarding schools in increasing human resources at Islamic Boarding Schools in Jambi Province

\subsection{Empowering Islamic Boarding Schools}

Empowerment is a "process of becoming" not an "instant process". As a process, empowerment has three stages, namely, awareness, capacity building and empowerment. In simple terms it can be explained as follows:

1) The first stage is awareness. At this stage the targets to be empowered are given "enlightenment" in the form of awareness that they have the right to have "something". For example, the target is a group of poor people. They are given an understanding that they can be, and that can be done if they have the capacity to get out of poverty. Programs that can be done at this stage for example provide knowledge that is cognition, belief, and healing. The basic principle is to make the target understand that they need (building "demand") is empowered and that the empowerment process starts within themselves (not from others).

2) The second stage is capacity building. This is what is often referred to as capacity building, or in languages that are simpler or enabling. To be given power or power, the person concerned must be able to first. For example, before giving regional autonomy, regions that are supposed to be autonomous should be given capacity building programs to make 
them "skilled" in managing the given autonomy. The capacity building process consists of three types, namely human, organization, and value systems.

3) The third stage is giving power itself - or empowerment in a narrow sense. At this stage the target is given power, power, authority or opportunity. This gift is in accordance with the quality of the skills that have been possessed.

Seeing some Islamic theories and sources described above, researchers can make a synthesis and indicator of empowerment in an educational institution, namely:

1) Empowerment in the management of education is part of economic empowerment, social empowerment, political empowerment and cultural empowerment.

2) In educational empowerment there are several elements that need to be implemented, namely: the application of integrated quality management (TQM) in education, the application of professionalism in education management, welfare improvement and the implementation of teacher performance development systems, enforcement of the legality of education.

3) There are five indicators of empowerment in improving the quality of education, namely: quality systems oriented to consumers, quality systems characterized by active participation in continuous quality improvement processes, quality systems characterized by an understanding of each of the specific responsibilities for quality, systems quality is characterized by the existence of activities that are oriented towards prevention of damage, not focusing on efforts to detect damage only, and the quality system is characterized by the existence of a philosophy which is assumed that quality is a way of life.

4) In Islam empowerment is the utilization of the potential that exists in every human being, to be empowered through the existence of shared responsibility towards the work done, caring for each other, so that mutual help appears and helps each other.

5) Principles of accountability in educational empowerment which include: commitment from the leadership, into an integrated system, can show the level of achievement of goals and objectives that have been set, oriented towards achieving the vision and mission and the results and benefits obtained, honest, objective, transparent, and innovative in the management of educational institutions, and performance accountability must also present an explanation of the deviation between the realization of activities with plans and the success and failure in achieving the goals and objectives that have been set.

\subsection{Human Resources}

Definition of HR can be divided into two, namely micro and macro understanding. Definition of Micro-based HR is individuals who work and become members of a company or institution and are commonly referred to as employees, laborers, employees, workers, labor and so on. While the definition of HR on a macro basis is the population of a country that has entered the age of the workforce, both those who have not worked and those who have worked.

Education and training is an effort to develop human resources, especially to develop intellectual abilities and human personality. While human resource management is the art of planning, organizing, directing, and overseeing the activities of human resources in order to achieve organizational goals. The need for human resources is well managed because humans always play an active and dominant role in every activity of the organization. 
Talking about the problem of human resources, we can actually see from two aspects, namely quantity and quality. Quantity concerns the number of human resources (population) whose contribution is less important in development, compared to quality aspects. Even the quantity of human resources without good quality will be a burden on the development of a nation.

Whereas quality concerns the quality of human resources, which concerns abilities, both physical abilities and non-physical abilities (intelligence and mental). Therefore, in the interests of accelerating a development in any field, improving the quality of human resources is a major prerequisite.

The quality of human resources involves two aspects as well, namely physical aspects (physical quality) and non-physical aspects (non-physical qualities) that involve the ability to work, think, and other skills. Therefore, efforts to improve the physical quality of human resources can also be sought through health and nutrition programs. Whereas to improve the quality or non-physical abilities, education and training efforts are the most needed. This effort is intended by the development of human resources.

From this description it can be concluded that what is meant by the development of human resources (Human Resources Development) on a macro basis, is a process of improving the quality or ability of humans in order to achieve a nation-building goal. From the various meanings above, what is meant by empowering human resources is a process of improving human quality or ability in order to achieve a set goal, with indicators: (1) education and (2) training.

\subsection{Research Approach}

The study on the empowerment of Islamic boarding schools in this study uses descriptive methods. This research attempts to describe and understand the pattern of Islamic boarding school empowerment in improving pesantren human resources as they are in a rounded unity. In that sense, the approach used is qualitative, which is an approach to find answers to the questions why a phenomenon appears or something that is meaningful.

Methodology in research is the whole process of thinking, the value of finding research problems then describes it in a particular theoretical framework, as well as collecting data for empirical testing up to an explanation and drawing conclusions from the problems studied.

This study uses a qualitative approach. It is called qualitative because the nature of the data collected is qualitative, not quantitative using a measuring device. Through this qualitative approach, it is expected that a picture of the quality, social reality and perceptions of the target of the research is lifted without being contaminated by formal measurement.

Research settings are contextualized in Islamic Boarding Schools in Jambi Province. The selection of settings is based on rational, practical, and economic considerations, that Islamic Boarding Schools in Jambi Province. In fact this shows that the selection of settings will make it easier for researchers to carry out research. 
The research subject will be centered on the leadership and management members or executors of the foundation, management and supervision of empowerment at Islamic Boarding Schools in Jambi Province, namely the parties most responsible and influential on the empowerment of Islamic boarding schools towards the improvement of pesantren human resources in Jambi Province. The research subject in question is all the elements of the boarding school management in Jambi Province and especially those who deal with the problem of Islamic boarding schools. Determination of the subject is purposive sampling, namely informants who have more information and influence in Islamic boarding schools in Jambi Province.

\subsection{Description of Locations, Findings and Analysis of Research Results}

\subsubsection{Description of Locations}

Ummul Masakin Islamic boarding school is a hut under the auspices of Ummul Masakin's foundation. Ummul Masakin, which means his mother is poor, was taken to be the name of the foundation which was established on April 21, 2011. Initially the foundation was located in RT. 12 Tebing Tinggi Village Kec. Pemayung Kab. Batang Hari Jambi Province. But in 2015 the Tebing Tinggi village experienced regional expansion so that the Ummul Masakin Foundation was included in the RT area. 01 Village of Kampung Pulau Pemayung District Kabaten Batang Hari. The foundation was established because of the concern of a mother who saw the economic situation of poor people, orphans, and underprivileged children who could not continue their education even though the study was an obligation for a Muslim, so that a foundation was expected to be built become a shade for institutions under its auspices.

The first institution in the form of Islamic Boarding School "UMMUL MASAKIN" was established on April 21, 2011, which took place in Kampung Pulau Village, Pemayung District, Batang Hari Regency, led by Ustadzah Dra. COMFORT. In addition to learning in the field of religion, santri also received lessons in general education with the establishment of an Integrated Islamic Middle School in the same year. It is intended that graduates of Islamic boarding schools can continue their studies to a higher level. Furthermore, Ummul Masakin's orphanage was established, which became known as the Child Social Welfare Institution (LKSA) and Ummul Masakin Private Madrasah.

Ummul Masakin Islamic Boarding School will try to explore the potential of human resources in the community in order to explore Islamic studies, knowledge, science and technology, especially in the younger generation who still have the desire to continue their education at a higher level but do not have the ability to financial side.

Islamic Boarding Schools UMMUL MASAKIN under the auspices of the UMMUL MASAKIN Foundation are salafiah Islamic boarding schools and memorize the Qur'an (hifzil Qur'an) and religious studies (diniyah). Even though there is an equal exam between junior and senior high school but the main mission in this Islamic boarding school is to study, learn to memorize the Qur'an and study the yellow book and learn the knowledge of religion and morality. 
The Operational Permit of the Batang Hari Regency Ministry of Religion was issued in Batang hari signed by the Head of the Ministry of Religion Office, Batang Hari Regency, with Number: KD. 05.4 / 5 / PP.00.7 / 49/2012 and Islamic Boarding School Statistics Number 512015043008.

\section{Findings and Analysis}

The leadership of the Islamic boarding school in the Regency of Batang Hari, which is seen in its huts in its daily life, has not fully been able to empower the human resources in the cottage. This can lead to the empowerment of the human resources of the cottage cannot be fully run properly. Human resource management is the main obstacle to innovating school management.

The initial recruitment process established by the Islamic Boarding School of the Islamic Boarding School of Batang Hari is to identify whether there are vacancies that can be identified through regular meetings to evaluate all activities that occur. The head of the lodge stated as explained earlier, we identified the presence or absence of office, after meeting with the syllabus team. If indeed there is a recruitment process. In addition, also from the teaching section report by looking at what teaching staff are lacking. These meetings usually consist of cottage leaders, foundation administrators, homerooms, elements of care. In addition, if needed DPK educators as explained previously we as the lodge will ask the government.

In addition, the MA chief explained how to identify job vacancies by looking at study groups. If indeed the study group is more than the previous year, the teacher needs to teach. The same thing was conveyed by the head of MTs, the number of study groups, the needs of teachers, the number of teachers who stopped.

In recruiting new teaching staff (teachers) it is necessary to determine what is the purpose of the recruitment activities as planning activities. From the results of the interview with TM as the leader of the Islamic Boarding School, Ummul Masakin explained that the goal was to get teachers who had good competence and in accordance with the needs of the pesantren. The same thing was also expressed by the head of the administration stating that in order to get needed educators so that it could help the process of developing Islamic boarding schools, so that these Islamic boarding schools were better.

The same thing will also be done by Ummul Masakin Islamic boarding school in the recruitment of educational staff (staff). Recruitment of education personnel in this case is usually called staff also must pay attention to the things that are fundamental in determining the educational staff needed. This was revealed by Mastari who stated that in the recruitment of education staff (staff) As someone who plays an important role in the process of progress of educational institutions, the education staff (staff) must have the competency to support their main performance. Education staff (staff) must have 4 competencies, including: Personal Competence, Expertise Competence, Social Competence, and Professional Competence.

The results of the analysis show that the internal support built by Ummul Masakin Islamic Boarding School through the leadership in the recruitment of education staff (staff) is very important. Because without the support of internal parties, the principal as a leader is not possible 
to realize the ideas and programs that have been planned. Education staff (staff) are internal factors that have a major contribution in improving the quality of schools.

The empowerment activities owned by Ummul Masakin Islamic Boarding School in increasing the pesantren's human resources began with the empowerment of educators and education personnel. Empowerment carried out by the lodge for educators and education through training that must be followed by clerics / religious teachers.

Education in general is related to preparing prospective personnel needed in a particular job or task. In a training, the orientation or emphasis is on the tasks to be carried out (job orientation), while education is more on developing general abilities. Training in general emphasizes psychomotor abilities, although based on knowledge and attitudes, while in education, the three areas of ability (cognitive, affective, psychomotor) receive balanced attention.

The empowerment carried out by Ummul Masakin Islamic boarding school towards educators and education staff was more focused on training. This is done so that the teaching staff and education staff gain experience, in addition to the knowledge obtained previously. With the training that was followed, it was hoped that the educators and education staff would obtain additional knowledge and experience that had not been obtained before.

The findings and results of the analysis of researchers in the empowerment of educators and educational staff conducted by Ummul Masakin Islamic Boarding School through training and activities that are able to increase the knowledge and abilities of educators and education personnel. With training and activities that are expected to improve performance in carrying out tasks. In addition, the teaching profession must have professional status that requires development. Likewise staff / employees as internal components have a role as brainpower or braintrust for the progress of the organization so it is very important to improve its human resources.

The principal (cottage leader) in working with employees has an obligation to improve the professionalism of employees. Their support determines the progress of the cottage. The cottage can run effectively if the head of the cottage is able to create an atmosphere of order, discipline, have goals and targets to be achieved.

\section{Analysis of Research Results}

Ummul Masakin Islamic Boarding School Batang Hari is a salaf hut that still preserves traditional learning systems, and implements education and teaching as the basic foundation for santri to have knowledge and abilities in the field of religion. It is hoped that education and teaching that prioritizes religious knowledge of the santri can apply and apply knowledge in empowering the community. Where the results of empowerment are in the form of becoming ulama or cadre da'i who understand the knowledge of religion. In preparing the cadres of ulama / da'ri, it is inseparable from the application of activities in Islamic boarding schools. This is to form the morality of santri so that the male and female santri can practice their knowledge in the community.

Based on the analysis of the researchers, from the santri empowerment programs which began with academic programs and non-academic programs, the results were quite good. In the creation of 
future scholars from the program that has been carried out for alumni it has reached $70 \%$, while for candidates becoming ulam, it is around $25 \%$.

\section{Conclusion}

In the recruitment of Ummul Masakin Islamic Boarding School educators and education staff, they first planned for the needs in the following stages: (a) Estimated Labor Needs; (b) Estimated Supply of Internal Human Resources. In recruiting educators and educational staff, Ummul Masakin Islamic Boarding School has several factors supporting the recruitment process. In the process of recruiting educators and educational staff at the Islamic boarding school of Ummah Masakin in Batang Hari Regency from internal and external sources, internal sources are usually obtained from alumni students who are willing to serve and dedicate themselves to Islamic boarding schools through a questionnaire filled with students after National Examination, while external sources are obtained from educators and education personnel outside the hut, through the process of sending job applications, followed by a selection process. The factors that are very relevant to this research can be classified into two factors, namely: (a) Internal factors in the form of: (1) Leaders of Islamic boarding schools; (2) Educators and Education Personnel; (b) External factors in the form of: (1) Development of science and technology; (2) Society. The inhibiting factors of the process of recruitment of educators and education personnel are: (1) Image of educational institutions; (2) Compensation Policy.

The activity of empowering Islamic boarding schools in improving pesantren human resources at Islamic Boarding School Islamic Boarding School in Batang Hari Regency there are several activities that can be followed by santri. All activities are prepared by the boarding school to increase the pesantren's resources. The empowerment activities of Islamic boarding schools here are in the form of the participation of the santri in community activities. The pesantren empowerment program is the creativity of the pesantren itself or it can also be the result of cooperation between pesantren and other institutions. Ummul Masakin Islamic Boarding School has its own creativity in implementing a santri-based empowerment program, the methods it runs are partially adopted from other Islamic boarding schools, and some others are only unique in Ummul Masakin Batang Hari.

In order for santri-based empowerment to run as expected, pesantren do the following methods: (1). The Santri Council as the Program Activator; (2). Form a Container for Appreciating the Potential of Santri (WAPOSI); (3). Alumni Service Program; (4). Typical Curriculum in Empowerment Education; (5). Buttom Coordination Up. The participation of santri in the empowerment of Islamic boarding schools is absolutely necessary, because the santri will carry out the program. The involvement of santri is expected to be more explored potential and creativity of the students.

Ummul Masakin Islamic Boarding School Batang Hari is a salaf hut that still preserves traditional learning systems, and implements education and teaching as the basic foundation for santri to have knowledge and abilities in the field of religion. In preparing the cadres of ulama / da'ri, it is inseparable from the application of activities in Islamic boarding schools. This is to form the morality of santri so that the male and female santri can practice their knowledge in the community. Ummul Masakin Islamic Boarding School Batang Hari is a boarding school for boys and girls, but 
in parenting it is divided into two: female students under direct care by Ustazah Husna while male students are under care by kyai Muji Salamun.

\section{References}

[1] Halim dkk, Manajemen Pesantren. Yogyakarta : LKIS, 2012.

[2] Abdullah Nasih, Kegiatan Kaderisasi di dalam Pendidikan Pondok Pesantren di Indonesia. Bandung : Raja Grafindo Persada. 2011.

[3] Aji, Kepengurusan Koperasi di Pondok Pesantren, Yogyakarta : Balai Pustaka, 2013.

[4] Ali Idrus, Manajemen Pendidikan Global Visi, Aksi, dan Adabtasi, Jakarta : Gaung Persada Press, 2009.

[5] Arief. A, Reformasi Pendidikan Islam. Jakarta : CRSD Press. 2008.

[6] Azyumardi Azra, Pendidikan Islam Tradisi dan Moderenisasi Menuju Melinium Baru. Jakarta: PT. Logos Wacanal Ilmu. 2009.

[7] Bailey, D. Using participatory research in community consortia development and evaluation: lessons from the beginning of a story. American Sociologist, 23 (4), 2012.

[8] Buchari Zainun, Manajemen Sumber Daya Manusia, Jakarta : Balai Pustaka, 2012.

[9] Cappelli, P., "HR Implications of Healthcare Reform," Human Resource Executive Online, March 29, 2010, accessed August http://www.hreonline.com/HRE/story.jsp?storyId=379096509.

[10] Departemen Agama R.I, Al-Qur'an dan Terjemahannya, Jakarta : Dirjen Kelembagaan Islam, 2009.

[11] Departemen Agama, Pola Pembelajaran Pesantren, Yogyakarta : Erlangga, 2009.

[12] Dewan Redaksi, Ensiklopedia Islam, Jakarta : Erlangga, 2009.

[13] Dhofier, Pendidikan Pondok Pesantren, Yogyakarta : Remaja Rosda Karya, 2010.

[14] Dokumen Pondok Pesantren Ummul Masakin, 2018

[15] Edi Suharto, Pemberdayaan Sumber Daya Manusia di Era Modern, Bandung : PT. Remaja Rosda Karya, 2012.

[16] Fasa, Koperasi Pesantren di Era Globalisasi. Jakarta : Erlangga. 2014.

[17] Fuad Jabali,dkk, IAIN, Modernisasi Islam di Indonesia. Jakarta : Logos. 2008.

[18] Hasil Observasi, Pondok Pesantren Ummul Masakin, 24 November 2018.

[19] Hermawan dan Suryono, Kepengurusan Koperasi di Pondok Pesantren. Bandung : PT. Remaja Rosda Karya. 2012.

[20] Hidayat dan Sumarno, Koperasi untuk Membantu Perekonomian Masyarakat. Jakarta : BPFE. 2012.

[21] Husaini Usman, Manajemen Sumber Daya Manusia, Jakarta : Erlangga, 2010.

[22] Imam At-Tabrani, dalam al-Mu'jam al-Awsat, No. 897, dan Imam Baihaqi dalam Sya'bu al-Iman, No. 5312.

[23] Imam Muslim dalam Shahih Muslim, Kitab al-Saidu wa al-Dzibahu wa Ma Yukalu Min alHiyawani, No. 1955

[24] Karel A. Steenbrink, Pesantren Madrasah Sekolah, Pendidika Islam dalam Kurun Modern, Jakarta : LP3 ES, 2010.

[25] Khan, Pemberdayaan Sumber Daya Manusia, Jakarta : Raja Grafindo Persada, 2011.

[26] Lukenes, Ronald Alan, Jihad ala Pesantren, Terj, Abdurahman Mas'ud, Terj, Abdurahman Mas'ud, Yogyakarta: Gama Media, 2004.

[27] M.Quraish Shihab, Tafsir al-Mishbah Pesan, Kesan, dan keserasian al-Qur'an, Volume 2, Cet 1. Ciputat: Lentera Hati, 2000.

[28] Malik, Pemberdayaan Santri di Pondok Pesantren di Indonesia, Bandung : Remaja Rosda Karya, 2011. 
[29] Mas'ud A, Dinamika Pesantren dan Madrasah. Dinamika Pesantren dan Madrasah, Yogyakarta: Pustaka Belajar. 2009.

[30] Mastari, Manajemen Sumber Daya Manusia pada Lembaga Pendidikan. Jakarta : Balai Pustaka, 2012.

[31] Matari, Manajemen Pemberdayaan Sumber Daya Manusia, Jakarta : Balai Pustaka, 2014.

[32] Merrian Webster, Oxford English Dicteonary, Columbus Ohio Meril, 2010.

[33] Modul Diklatpim Tingkat III, Pemberdayaan Sumber Daya Manusia, (Jakarta : Lembaga Administrasi Negera-Republik Indonesia), 2008.

[34] Mubyartanto, Pemberdayaan Sumber Daya Manusia, Bandung : Remaja Rosdakarya, 2012.

[35] Nasir, Pendidikan dan Kehidupan Santri di POndok Pesantren. Jakarta : Balai Pustaka, 2009.

[36] Nurcholis Madjid, Bilik-bilik Pesantren, Jakarta : Paramadina, 2011.

[37] Oos M. Anwas, Pemberdayaan Masyarakat di Era Global, Bandung Alfabeta, 2013.

[38] Peraturan Menteri Agama Republik Indonesia Nomor 13 Tahun 2014 tentang Pendidikan Keagamaan Islam.

[39] Peraturan Menteri Agama Republik Indonesia Nomor 3 Tahun 2012 tentang Pendidikan Agama Islam.

[40] Peraturan Pemerintah Republik Indonesia Nomor 55 Tahun 2007 tentang Pendidikan Agama dan Pendidikan Keagamaan.

[41] Prolog Abdurrahman Wahid, Pesantren Masa Depan, Bandung: Pustaka Hidayah, 2009.

[42] Rangkuti, Koperasi di dalam kehidupan masyarakat, Jakarta : Erlangga, 2011.

[43] Saugi dan Sumarno, Perkembangan Koperasi di Pondok Pesantren, Bandung : Alfabeta, 2015.

[44] Sayyid Quthb, Tafsir fi Zhilalil Qur'an, (terj), As'ad Yasin, Jakarta: Gema Insani Press, 2002.

[45] Siagian, Sondang P. Manajemen Sumber Daya Manusia, Jakarta: Bumi Aksara, 2005.

[46] Soekidjo Notoatmojo, Pengembangan Sumber Daya Manusia, Jakarta: Rineka Cipta, 2013.

[47] Soekidjo Notoatmojo, Pengembangan Sumber Daya Manusia, Jakarta: Rineka Cipta, 2013.

[48] Sriharini. Pondok Pesantren dan Pemberdayaan Ekonomi Masyarakat, Yogyakarta: Jurnal PMI Media Pemikiran Pengembangan Masyarakat, 2013.

[49] Sukamto, Kepemimpinan Kiai dalam Pesantren, Jakarta: Pustaka LP3ES, 1999.

[50] Syukur F. Manajemen Sumber Daya Manusia Pendidikan. Jakarta: Pustaka Rizki Putra, 2012.

[51] T. Hani Handoko, Manajemen Rekrutmen Karyawan, Jakarta : Remaja Rosda Karya, 2008.

[52] Teresa, Aprilia, dkk, Pembangunan Berbasis Masyarakat Acuan bagi Praktisi, Akademisi, dan pemerhati Pembangunan Masyarakat, Bandung: Alfabeta, 2014.

[53] Tony Bush, Leadership and Management Development in Education, London: Sage Publishing, 2008.

[54] UU No. 43 Tahun 1999., tentang tenaga kerja.

[55] Widjajanti, Masyarakat Mandiri bersama Koperasi. Yogyakarta BPFE, 2012.

[56] Wuradji, Pemberdayaan sumber daya manusia di dalam masyarkat. Jakarta : Erlangga, 2011.

[57] Ziemek Manfred, Pesantren dalam Perubahan Sosial, Jakarta: P3M. 2010.

[58] Zuhri, Pesantren dalam pandangan Masyarakat. Jakarta: Erlangga. 2010. 